\title{
GEOECONOMICS- A NEW DIRECTION IN THE CONDUCTION OF GEOPOLITICS AND INTERNATIONAL RELATIONS
}

\author{
MA Zoran Vasileski \\ $\mathrm{PhD}$ Candidate at the Institute for Security, \\ Defense and Peace-Faculty of Philosophy Skopje \\ E-mail: zorvas74@gmail.com \\ MA Stojanche Masevski \\ $\mathrm{PhD}$ Candidate at the Institute for Security, \\ Defense and Peace-Faculty of Philosophy Skopje \\ E-mail: stole_k2@hotmail.com
}

\begin{abstract}
The modern world and the countries in it in the last twenty years have entered a new phase in which international politics and national security are increasingly inclined around economic interests. The shaping of the world stage and the key issues that arise from it will be left more and more to the economy. Heads of state in an effort to maintain or strengthen their position on the world stage seek to replace the declining role of geopolitics with geoeconomics in order to achieve national goals and interests.

If geopolitics and military power in the twentieth century were the main tool for achieving the goals and interests of states, that role is now in the twenty-first century left to geoeconomics and economic power. The goal has not changed at all, only the means have changed and thus their efficiency and effectiveness.

It is more than obvious that we are entering a phase when international politics and thus international relations are increasingly revolving around the economic interests of states. Economic diplomacy is becoming a key factor in shaping relations between states and other entities on the international stage. Geoeconomic competition is an unfair competition where the rules and ideologies on which the economy is based do not apply. Empirically, geoeconomics is becoming a basic parameter of the international order, international hierarchy and relations between states.
\end{abstract}

Keywords: geopolitics, geoeconomics, geopolitical pressure, geoeconomics competition 


\title{
ГЕОЕКОНОМИЈА - НОВ ПРАВЕЦ ВО ВОДЕЊЕТО НА ГЕОПОЛИТИКА И МЕЃУНАРОДНИ ОДНОСИ
}

\author{
м-р Зоран Василески \\ докторанд на Институтот за безбедност, \\ одбрана и мир - Филозофски факултет Скопје \\ E-mail: zorvas74@gmail.com \\ м-р Стојанче Масевски \\ докторанд на Институтот за безбедност, \\ одбрана и мир - Филозофски факултет Скопје \\ E-mail: stole_k2@hotmail.com
}

\begin{abstract}
Апстракт
Современиот свет и државите во него во последниве дваесетина години влегоа во една нова фаза во којашто меѓународната политика и националната безбедност инклинираат сѐ повеќе околку економските интереси. Обликувањето на светската сцена и клучните прашања кои произлегуват од неа ќе бидат препуштени сѐ повеќе и повеќе на економијата. Шефовите на државите во обид да ја задржат или да ја зајакнат позицијата на светската сцена настојуваат да ја заменат опаѓачката улога на геополитиката со геоекономијата со цел остварување на националните цели и интереси.

Доколку геополитиката и воената моќ во дваесетиот век беа главното орудие за постигнување на целите и интересите на државите, таа улога сега во дваесет и првиот век е препуштена на геоекономијата и економската моќ. Целта воопшто не е сменета, сменети се само средствата, а со тоа и нивната ефикасност и ефективност.

Повеќе од очигледно е дека влегуваме во фаза кога меѓународната политика, а со тоа и меѓународните односи сѐ повеќе и повеќе ротираат, отколку економските интереси на државите. Економската дипломатија станува клучен фактор во обликувањето на односите помеѓу државите и другите субјекти на меѓународната сцена. Геоекономскиот натпревар претставува неправеден натпревар каде што не важат правилата и идеологиите на кои се базира економијата. Емпириски гледано, геоекономијата станува основен параметар на меѓународниот поредок, меѓународната хиерархија и односите помеѓу државите.
\end{abstract}

Клучни зборови: геополитика, геоекономија, геополитички притисок, геоекономски натпревар 


\section{1. Вовед}

Во реалноста не постои ниедна призната научна гранка која може да го објасни судирот на економските интереси во планетарен размер освен геоекономијата.

Од ставовите на економската теорија, геоекономијата е прекугранична политичка економија заснована на еден неправеден натпревар каде што не важат правилата и идеологиите на кои се базира економијата. Емпириски, геоекономијата станува основен параметар на меѓународниот поредок затоа што воената моќ ја губи традиционалната улога што ја одредува хиерархијата на државите. Задача на геоекономијата е да изгради стратегија за дејстување на државата, така што ке може да им обезбеди на своите компании и на нејзината економија конкурентска предност ${ }^{1}$, но и да помогне врз формирањето на политиките за национална безбедност и сите стратегиски документи, планови и концепции што произлегуваат од неа.

Како главни носители на геоекономијата и геоекономските политики, секако ќе бидат државите, но не помалку важни ќе бидат и големите економски единици (организации и мултинационални компании). Геополитичкиот амбиент, a со тоа и геополитичките притисоци за државите ќе бидат надополнети и со геоекономски притисоци за кои државите ќе треба да посветат значително внимание и да заземат сеопфатен пристап афирмирајќи ги и нив како важна детерминанта при формулирањето на националната безбедност. Геополитичката транзиција го менува карактерот на структурата и процесите во меѓународниот систем. ${ }^{2}$ Согласно гледиштата на Милески, создавањето на светската политичка карта претставува резултат на политиката на моќ ${ }^{3}$, која во последните години е надополнета и со политиката на економска моќ. Геополитиката претставува составен дел од политиката на државата. ${ }^{4}$

Во новиот геополитички натпревар, иако не владеаат никакви правила секоја држава без разлика на нејзината големина, број на население, развиеност и економско-политичка моќ во светски рамки ќе мора да учествува. Нејзиното учество е од витално значење ако сака да опстои како самостојна, суверена и независна држава призната во светски рамки. Шефовите на државите во обид да ја задржат или да ја зајакнат позицијата на светската сцена настојуваат да ја заменат опаѓачката улога на геополитиката со геоекономијата со цел

\footnotetext{
${ }_{1}^{1}$ Бабић, Б. (2019). Геоекономија и неутралност Србије. Војно дело. број 8/2019, стр. 182.

2 Милески, Т. (2015). Политичка географија и геополитика. Скопје: Филозофски факултет, стр. 192.

${ }^{3}$ Милески, Т. (2004). Политичко-географскиот процес како детерминанта на формирањето на политичката карта. Современа македонска одбрана. број 9 година IV, стр. 93.

${ }^{4}$ Милески, Т. (2005). Македонија- Рубикова коика на Балканот. Скопје: Филозофски факултет, стр. 23
} 
остварување на националните цели и интереси. ${ }^{5}$

\section{2. Геоекономија}

\section{1 Потекло на геоекономијата}

Потеклото на геоекономијата според Бару (Sanjay Baru) ${ }^{6}$ е во меркантилизмот од седумнаесетиот век. Тогаш државите се потпирале на воената моќ, настојувале да обезбедат пазари, природни богатства и благородни метали. Главно начело на меѓународната трговија било да се извозува што повеќе, а да се увезува што помалку. ${ }^{7}$

Изразот геоекономија прв во 1942 година го употребил Ренер (George T. Renner), меѓутоа Лутвак (Edward Luttwak) е запамтен како „кум“ на геоекономијата како посебна научна дисциплина. Тој прв пробал теориски да го дефинира поим геоекономија во написот „Од геополитика кон геоекономија: логика на конфликти, трговска граматика“ (1990). Тој пробал да докаже дека геоекономијата има засебен предмет и метод и на тој начин да ја раздели од геоекономијата. Геоекономијата според Лутвак претставува ново орудие за постигнување на целите на високоразвиените држави во меѓународните односи по пат на геоекономски, а не воени стратегии. Истовремено, настојувал да за заштити геоекономијата и од меркантилизмот и економската војна. ${ }^{8}$ За да се оствари оваа негова замисла потребни се определени средства со кои ке се служи геоекономијата, односно потребно е да се изврши и дефинирање на самите носители на геоекономијата.

\section{2 Носители и средства на геоекономијата}

Главни носители на геоекономијата се државите и големите економски единици. ${ }^{9}$ Денес меѓународната конкуренција и хиерархијата на државите се повеќе зависат од економијата. Понатаму, во гледиштата на Лутвак во овој современ свет, државите пробуваат да го подигнат нивото на нивна компетентност во меѓународната економска конкуренција. ${ }^{10}$ Државата има преовладувачка улога во освојувањето на странските пазари и постигнувањето супериорност. ${ }^{11}$

\footnotetext{
${ }^{5}$ Luttwak, E. (1990). From Geopolitics to Geo-Economics. Logic of Conflict, Grammar of Commerce. The National Interest. No. 20, p.19.

${ }^{6}$ Sanjaya Bary е политички коментатор и политички аналитичар. Служел и како генерален секретар на федерацијата на индиски трговски и индустриски комори. Бил директор и на одделението за геоекономија и стратегија на меѓународниот институт за стратешки студии.

${ }^{7}$ Sanjaya B. (2012). Geoeconomics and strategy. Survival, Vol. 54, No 3, pp.47-58.

${ }^{8}$ Luttwak, E. (1990). From Geopolitics to Geo-Economics. Logic of Conflict, Grammar of Commerce. The National Interest. No. 20, pp.17-23.

${ }^{9}$ Luttwak, E. (1990). From Geopolitics to Geo-Economics. Logic of Conflict, Grammar of Commerce. The National Interest. No. 20, p.19.

${ }^{10}$ Ibid.

${ }^{11}$ Ibid.
} 
Најсликовито и најживописно ова го има изразено Бару според кого знамето ја следи трговијата и трговијата го следи знамето. Бизнисите исто така можат да имаат геоекономски стратегии како државите. Но, на големите компании им е потребна државна поддршка на светска сцена. На тој начин, постои реципроцитет меѓу нив и државата. Државите може да имаат интерес да ги насочуваат големите претпријатија претворајќи ги во нивните „избрани средства“. Сепак, компаниите исто така можат да ги користат државите како алатки во нивната меѓународна економска стратегија. Постои и трето решение: државите и големите компании да се сметаат едни за други како нивни инструменти. Најчесто, сепак, државата и компанијата дејствуваат во хармонија - првиот помага и ги поддржува амбициите на другиот - целосно свесни за стратешките императиви на двајцата. Општо земено, повеќето научници во земјата го гледаат главниот носител на геоекономијата, а геоекономијата како научна дисциплина која го проучува светското економско ривалство чии главни носители се државите. ${ }^{12}$

Геоекономијата е ново издание на старото ривалство меѓу државите. Во него капиталот за инвестиции во индустријата обезбеден или насочен од државата е еквивалент на огнено оружје; развојот на производи со државни субвенции е еквивалентен на обука за оружје; и пенетрацијата на пазарот со помош на државата ги заменува воените бази и гарнизоните на странско тло, како и дипломатското влијание. Дури и ако воената моќ на светско ниво целосно исчезнеше и на неа останеа само економски деловни единици, логиката на трговијата ќе доведе до остро ривалство или до создавање сојуз меѓу нив. И во двата случаи, односно во случај на ривалство и во случај на создавање сојуз меѓу деловните единици, дејствувањето од сите страни секогаш би се одвивало без оглед на границите.

Во геоекономскиот натпревар, се користат низа на економски средства: царинска заштита на важни економски гранки, субвенционирање на клучни компании, повластено позајмување, даночно олеснување, особено поттикнување развој на избрани активности, развој на нови технологии, конкуренција за природни ресурси и инфраструктура и слично. Важноста на одделни земји од гледна точка на геоекономијата ќе зависи од клучните области - движењето на стоки, финансии, луѓe, технологија и информации. Од самиот овој натпревар се јавуваат и определени ризици, закани но и предизвици со кои мора да се носат земјите.

\section{3 Геоекономски предизвик}

Секоја земја, без оглед на политичкиот избор што ќе го избере, ќе мора да се пресмета со геоекономските предизвици. Без оглед на географските, демографските и економските димензии, таa мора да изгради сопствена

${ }^{12}$ Бабић, Б. (2019). Геоекономија и неутралност Србије. Војно дело. број 8/2019, стр. 183. 
геоекономска стратегија за да се справи со надворешните геоекономски и геополитички притисоци. Геоекономските прашања заслужуваат најголемо внимание на носителите на власта. Без да се земе предвид геоекономскиот фактор во нејзината внатрешна и надворешна политика, економски слабата земја не може да опстојува во модерниот свет. Во современи услови, ниту една економија не може да се огради од надворешната конкуренција. За да опстане националната економија во жестоко меѓународно ривалство, не е доволно само да се брани, туку мора да влегува во и борба. Победата бара мудра отвореност, со силна поддршка за домашните моќни и ветувачки производители, а за тоа се потребни добро осмислена долгорочна сеопфатна геоекономска стратегија и државен апарат способен да ја реализира таа стратегија. ${ }^{13}$

\section{3. Геоекономија наспроти геополитика}

Помеѓу геоекономијата и геополитиката постојат значајни разлики. Прво, геополитиката е научна дисциплина која се бави со изучување на спротивставеностите и споровите под кои стои намерата за завладување на политички простор односно територија и население што живее на нив (американското влијание и владение низ светот, односот на Русија кон Украина), а геоекономијата се бави со спротивставеностите и споровите позади кои стои намерата за завладување на определен економски простор (кинеско продирање на Балкански Полуостров и Африка). Нејзината цел не е да воспостави власт над територијата туку трговска и технолошка надмоќ. Второ, геополитиката се потпира на употреба на сила, вклучително и воена (инволвираност на Израел во Палестина, Азербеџан во Нагорно Карабах), додека геоекономијата се потпира на економски средства и го исклучува насилството како што е вооруженото и економското односно блокади и ембарга (влијанието на ЕУ во Европа, влијанието на Русија во „Стан Републиките“ во Азија, економското ширење на Кина во Азија и светот). Трето, исходот од политичките судири имаат нулта збир, додека трговските судири тоа не мора да го имаат (во геополитиката не се возможни двајца победници наспроти геоекономијата). ${ }^{14}$ Четврто, сцената на геокономијата не е територијата во физичка смисла на зборот, туку виртуелниот и флуиден простор чии граници постојано се поместуваат и ги надминуваат територијалните односно физичките граници типични за геополитиката. (пазар и технологија наспроти територија и население). На крај, со геоекономијата исклучиво управуваат државата и големите компании, додека списокот актери во геополитиката е многу подолг и покомплексен (држави, меѓународни организации, регионални организации, сојузи, етнички групи, народи и слично). Геоекономијата подразбира анализа на економските стратегии на државите или

${ }_{13}^{13}$ Бабић, Б. (2019). Геоекономија и неутралност Србије. Војно дело. број 8/2019, стр.186.

${ }^{14}$ Бабић, Б. (2019). Геоекономија и неутралност Србије. Војно дело. број 8/2019, стр.185. 
нивните надворешно-трговски стратегии. Таа е надополнување, а не замена за геополитиката. ${ }^{15}$

Нееднаквите потреби во услови на ограниченост на ресурсите го наметнува прашањето за економскиот избор. Економскиот избор во услови на ограничени ресурси бара рационалност во алокацијата на расположливите ресурси од аспект на економска ефикасност. ${ }^{16}$ Од овие причини постои геоекономски натпревар помеѓу државите кои се води со економски инструменти (односи) со цел јакнеење на сопствената економија. Желбата за моќ не е продукт на геополитиката, напротив желбата за моќ ја издигнува геополитиката на пиедестал. ${ }^{17}$

\section{4. Геоекономија и меѓуународни односи}

Сегашниот геополитички поредок ги уредува меѓусебните прашања преку организација на светскиот пазар и трговијата чиј политички израз се наднационалните интеграции во меѓуународните организации. ${ }^{18}$ Тој претставува концепт со кој во геополитиката се објаснува сложеноста на односите кои владеат во геополитичкиот систем. Поредоците претставуваат комбинација на социјални, политички и економски структури. Оттука тие се поврзани со светската економија односно со растотот и падот на големите економски сили кои вооедно биле и политички сили низ историјата. ${ }^{19}$ Тие се збир на вообичаени правила, институции, активнсоти и стратегии низ кои делувала и делува меѓународната политичка економија во различни историски периоди. Моменталниот светски геополитички поредок во кој живееме низ просторот е претставен преку геополитика на глобализмот, универзализмот и геоекономијата, а во кои постои мешавина од соработка и судири во односите помеѓу актерите.

Според гледиштата на Милески геополитичките играчи настојуваат да го устројат глобалниот геополитички поредок ${ }^{20}$ Современите геополитички односи можат да се разберат и како смена на хегемонистички циклуси кои ја карактеризираат поновата историја. На политичката карта на светот, во современи услови дејствуваат два привидно спротивни процеси. Глобализацијата како

\footnotetext{
${ }^{15}$ Милески, Т. (2015). Политичка географија и геополитика. Скопје: Филозофски факултет, стр. 202.

${ }^{16}$ Милошевић Г., Стајић Љ. (2018). Индикатори економске безбедности-осврт на Републику Србију. Зборник радова Правног факултета. бр. 2, стр. 512.

${ }^{17}$ Милески, Т. (2006). Геополитички модел за процесирање на геополитички настани. Современа македонска одбрана. број 14 година V, стр. 70.

18 Милески, Т. (2015). Политичка географија и геополитика. Скопје: Филозофски факултет, стр.75.

19 Милески, Т. (2015). Политичка географија и геополитика. Скопје: Филозофски факултет, стр.183.

${ }^{20}$ Милески, Т. (2016). Геополитичка положба на Република Македонија: Студија за постојани геополитички влијанија и трансформации. Геополитичката и геостратегиската положба на Република Македонија во услови на мигрантската и бегалската криза. МАНУ, стр. 91.
} 
процес кој се стреми кон создавање една супердржавна платенарна заедница и фрагментација која се стреми кон политичко-територијално ситнење на повеќенационални држави и создавање помали релативно независни национални држави. ${ }^{21}$

Создавањето на светската политичка карта претставува резултат на политиката на моќ. Тоа е карта на променливи модели со губитници и победници. Понатаму во погледите на Милески територијата создава платформа, суверенитетот оправдување, но ниту едното ниту другото не претставува адекватна одбрана за една држава против успешна акција спроведена од позиција на политика на моќ на ривалска држава кога станува збор за елиминирање од светската сцена. ${ }^{22}$

Денес секоја држава може да има надворешна еконономска политика која е предуслов за просперитет на нацијата. Глобализацијата доведе до замаглување на националните и меѓународните граници, последователно доведувајќи ја во прашање и самата безбедност на државата. Поради оваа причина, државите и нивните економии мораат да имаат геополитичка визија како би развиле геоекономска стратегија што долгорочно би им овозможило развивање на нивното меѓународно економско влијание. ${ }^{23}$

За една политичка единица особено значајно е признавањето на нејзината меѓународна индивидуалност односно признавање од страна на другите држави во меѓународната заедница. ${ }^{24}$ За да се случи тоа таа мора да исполни неколку услови. Политичката власт е само еден облик на владеење со просторот. Другите два кои исто така се применуван облик на владеење со просторот се економската доминација и воената контрола на одредена територија. Тие честопати се надополнуваат или претходат еден на друг. Доколку државата успее да ги задоволи овие три услови таа ќе биде способна за опстојување и водење на меѓународни односи.

Геоекономијата дава една нова фаза во водењето на меѓународните односи помеѓу државите. Доколку истите во минатото се воделе врз основа на зацртани геополитички цели, а со помош на воени, политички или економски средства, сега односите се надополнети и со геоекономски цели. Донекаде може да се каже дека геоекономијата е ново орудие за постигнување на целите на високоразвиените држави во меѓународните односи по пат на геоекономски стратегии. Како геоекономски цели кои се јавуваат кај секоја држава се ${ }^{21}$ Милески, Т. (2015). Политичка географија и геополитика. Скопје: Филозофски факултет, стр. 99.

22 Милески, Т. (2015). Политичка географија и геополитика. Скопје: Филозофски факултет, стр. 244.

${ }^{23}$ Grubić A. (2014). Nacionalna sigurnost iz perspektive geoekonomije: slučaj Republike Hrvatske. Međunarodne studije. Vol. 14 No. 1, стр. 69.

${ }^{24}$ Милески, Т. (2015). Политичка географија и геополитика. Скопје: Филозофски факултет, стр. 101. 
заштита на националната економија, помош на домашните претпријатија при совладување на технологии или при освојување на делови од светски пазар кои се однесуваат на производство или комерцијализација на критични производи, достигнување на високо ниво на економско техничко-технолошки развој, протекционизам на сопствениот пазар и слично. Ова најмногу се должи на сознанието дека интензивниот развој на современите држави кој исклучиво се базира на сопствените ресурси неизбежно води до самоисцрпување односно до намалување на изгледите да се излезе на крај со конкуренцијата. ${ }^{25}$ За да не дојде до самоисцрпување, а со цел да се намали притисокот, ризикот и негативниот став и можните реперкусии на останатите државите при употреба на воени средства и политички средства во меѓународните односи се повеќе се преземаат економски мерки за јакнеење на сопствениот економски амбиент и потенцијал, а со тоа и подобрување на сопствената меѓународна положба.

Правовремените економски мерки обезбедуваат автономност и јакнеење на економските позиции на земјата. Набљудувајќки го економскиот амбиент можеме да ги слогледаме предностите и недостатоците на економскиот потенцијал на државите, но и причините и последиците од одредени движење во развојот на општествата. ${ }^{26}$ Ова значи дека јакнењата на стратешки партнерства помеѓу државите, развивање на сестрани партнерски односи со земјите членки на најразлични меѓународни организации (ЕУ, НАТО, ОБСЕ, ООН), соработка со останатите значајни актери на меѓународна сцена (пред сѐ САД, Русија и Кина), промовирањето добрососедски односи и пријателства, склучувањето на билатерални, регионални договори за слободна трговија, учеството на иницијативи за регионална соработка во регионите каде просторно се наоѓаат државите се со цел јакнеење на меѓусебната доверба, пристап до пазарите, давање на активен придонес за подобрување на безбедноста, стабилноста и соработката, но и за привлекување на директни странски инвестиции. Геоекономијата со нејзините средства, цели и предизвици е еден нов правец во водењето на меѓународните односи. Тоа е така од причина што комплексноста на самите меѓународни односи бараат нови поефикасни модели на дејствување. Поголемиот дел од државите од првиот ешалон и/или од вториот ешалон ја имаат препознаено улогата и важноста на економијата. Државите ја имаат сфатено дека економското освојување на определен пазар претставува и економско, политичко и воено освојување на територијата на тој пазар без загуби во воена или политичка смисла.

Светот се менува, а со тоа се менуваат и односите помеѓу државите меѓусебе и односите помеѓу државите и организациите. Единиците во меѓународните односи го имаат осознаено фактот дека иднината е во (гео)економските односи

\footnotetext{
${ }^{25}$ Милески, Т. (2015). Политичка географија и геополитика. Скопје: Филозофски факултет, стр. 118.

26 Стајић Љ,, Милошевић Г. (2017). Финансијска делатност државе као фактор економске безбедности-осврт на Републику Србију. Српска политичка мисао. бр.1, стр. 176.
} 
и дека новиот поредок покрај другото ќе почива и на економски постулати. Употребата на сила и заканата за употреба на сила во остварување на целите на државите и заемните односи помеѓу нив ќе стане реликтија на минатото. Додека употребата на економски средства во водењето на меѓународните односи, односно постигнување на сопствените национални цели ќе биде поефикасно и поефективно.

Сепак ова не значи дека во водењето на меѓународните односи сѐ е препуштено на геоекономијата, напротив геоекономијата е само надополнување на геополитиката кога станува збор за водење на меѓународните односи. Во постигнување на своите интереси, државите на меѓународната сцена сѐ уште ќе се служат со геополитиката и со средствата што произлегуваат од неа. Геоекономијата пред сѐ ќе биде орудие на високоразвиените земји, додека геополитиката и нејзините средства (воена и политичка моќ), пред сѐ ќе бидат на располагање на земјите во развој и неразвиените земји во меѓународните односи.

Какоштое напочетокот наведеногеоекономијата станува основен параметар на меѓуннародниот поредок затоа што воената моќ ја губи традиционалната улога што ја одредува хиерархијата на државите. Искуствено, Франција во односите co ЕУ води геоекономија, додека со африканските земји покрај геоекономија води и геополитика. Истото се однесува и на Велика Британија. Од друга страна Кина, во нејзините односи со САД, Русија води и геополитика и геоекономија, а во односите со Јужна Кореја и Јапонија, пред сѐ води геополитика. Основата на водењето на односите помеѓу земјите ќе зависи од целите што тие ќе сакаат да ги постигнат (економско, политичко или воено завладување на просторот).

Ова не значи дека високоразвиените земји нема да водат геополитика, а земјите во развој и неразвиените земји нема да водат геоекономија, напротив и едните и другите ќе ги користат сите алатки кои им се на располагање само во различен обем, фрекфенција и големина за постигнување на националните интереси при водењето на меѓународните односи.

\section{5. Заклучни согледувања}

Крајот на Студената војна доведе до нови околности, да економијата има приоритет при дефинирање на безбедносно опкружување кое вклучува редефинирање на моќ и простор односно „виртуелен“ простор, движење и редефинирање традиционални концепти на односот помеѓу геополитиката и меѓународните односи. Останува фактот дека геополитиката е сѐ уште важен фактор кога се одлучува на кој начин да се дејствува во меѓународно опкружување, но е подобрен во смисла дека е дадена поголема предност на геоекономската рамка. Геополитичките играчи и понатаму ќе настојуваат да го устројат глобалниот геополитички поредок согласно нивните замисли и 
национални интереси. Без разлика дали во меѓународните односи ќе постои една или повеќе суперсили, геополитичкиот поредок ќе се базира на соработка и судири помеѓу државите.

Сепак светот се менува, а со тоа се менуваат и односите помеѓу државите меѓусебе и односите помеѓу државите и организациите. Истите имаат сфатено дека новиот светски поредок меѓу другото ќе се гради и на економски постулати. Борбата за продор на други пазари, технолошки развој, технички достигнувања, заштита на националните економии ќе биде акцентирано при водењето на меѓународните односи. Со тоа геоекономијата со нејзините средства, цели и предизвици ќе претставува еден нов правец во водењето на меѓународните односи, но ова не значи дека во водењето на меѓународните односи сѐ ќе и биде препуштено на геоекономијата, напротив геоекономијата е само надополнување на геополитиката кога станува збор за водење на меѓународните односи.

Сите држави живеат во специфичен просторно-временски контекст и за да им опстанат националните економии во жестоко меѓународно ривалство, а со тоа и да опстојат и учествуваат на меѓународната сцена не е доволно само да се бранат, туку мора да влегуваат и во борба. Водењето на рамноправни меѓународни односи сепак за одредени држави ќе биде императив и од таa причина ќе мора да работат во насока на зајакнување на својата економска дипломатија и користење на сите алатки од областа на економската политика кои ѝ се на располагање. Иако малите земји, земјите во развој и неразвиените земји ќе имаат потешкотии во водењето на геоекономија во меѓуународни односи, современиот геополитички амбиент и поредок како и сите ризици и притисоци кои произлегуваат од нив ќе ги приморуваат на преземање на такви чекори за опстојување на меѓународната сцена и учество во меѓународните односи. Во дваесет и првиот век, економската стабилност е клучна за да се обезбеди одржување на поволна позиција на меѓународната сцена и при водењето на меѓународни односи.

\section{6. Користена литература}

1. Бабић, Б. (2019). Геоекономија и неутралност Србије. Војно дело. број $8 / 2019$;

2. Grubić A. (2014). Nacionalna sigurnost iz perspektive geoekonomije: slučaj Republike Hrvatske. Međunarodne studije. Vol. 14 No. 1;

3. Luttwak, E. (1990). From Geopolitics to Geo-Economics. Logic of Conflict, Grammar of Commerce. The National Interest. No. 20;

4. Милески, Т. (2004). Политичко-географскиот процес како детерминанта на формирањето на политичката карта. Современа македонска одбрана. број 9 година IV;

5. Милески, Т. (2005). Македонија- Рубикова коика на Балканот. Скопје: Филозофски факултет; 
6. Милески, Т. (2006). Геополитички модел за процесирање на геополитички настани. Современа македонска одбрана. број 14 година V;

7. Милески, Т. (2015). Политичка географија и геополитика. Скопје: Филозофски факултет;

8. Милески, Т. (2016). Геополитичка положба на Република Македонија: Студија за постојани геополитички влијанија и трансформации. Геополитичката и геостратегиската положба на Република Македонија во услови на мигрантската и бегалската криза. МАНУ;

9. Милошевић Г., Стајић Љ. (2018). Индикатори економске безбедностиосврт на Републику Србију. Зборник радова Правног факултета. бр. 2;

10. Sanjaya B. (2012). Geoeconomics and strategy. Survival, Vol. 54, No 3;

11. Стајић Љ,, Милошевић Г. (2017). Финансијска делатност државе као фактор економске безбедности-осврт на Републику Србију. Српска политичка мисао. бр.1. 